\title{
THE FRONT POPULAIRE: VIEWS FROM THE RIGHT ${ }^{1}$
}

To this day, the mere mention of Léon Blum and the Front populaire in French rightist circles can instantly transform a quiet conversation into a fine display of Gallic political passion. Startling at first, such violent reactions, so many years after the fact, become more intelligible when viewed in proper perspective. For, to the many Frenchmen who remain convinced that they lived under communism from June, 1936, to June, 1937, l'expérience Blum was indeed a "Nightmare in Red".2

It should be noted at the outset that the terms "right" and "left", "extreme right" and "extreme left", no longer connote the clear-cut distinctions of simpler days. René Rémond has written of the perpetuation and evolution of not one but three "rights" in France; while Eugen Weber has warned us of the danger of putting "new wine in old bottles". ${ }^{3}$ The picture was further confused in the I930's by the emergence of what Blum himself called a "fascism of the left".4 From January to May, 1936, however, the country was split in two by the electoral alliance of the Communists, Socialists, and Radical-

${ }^{1}$ A slightly different version of this article was delivered as a paper at the annual meeting of the American Historical Association, The Sheraton Hotel, Philadelphia, December 29, 1963. The documentation was gathered during a period of research in France (June to December, 196r), sponsored in part by grants from the American Philosophical Society and Drexel Institute of Technology.

2 This is the quasi-unanimous opinion of the former members of rightist organizations the author has interviewed over the years. It is not without significance that, as late as 1959 , François Herbette should publish a collection of the Bulletin quotidien de la Société d'Etudes et d'Informations économiques, for the period $193^{6-1938}$, under the title l'Expérience Marxiste en France (Paris, 1959).

3 René Rémond, La Droite en France (Paris, 1954); Eugen Weber, "New Wine in Old Bottles: Les Familles Spirituelles de la France", in: French Historical Studies (Vol. I, No. 2, 1959), pp. 200-225.

4 Les Evénements survenus en France de 1933 à 1945: Témoignages et Documents recueillis par la Commission d'Enquête parlementaire (Paris, 1947), I, pp. 1 22-123. 
Socialists: "on one side stood the France of the Leagues and the right, on the other the France of the Front populaire."1 We may thus lump on the right, all those who opposed the Front populaire. This would include a variety of tendencies ranging from moderate right of center parties in the Chamber, to partisans of an authoritarian solution, reached by whatever means necessary, outside of Parliament. Appearances to the contrary, the victory of the Front populaire coalition was not the result of a decisive shift from right to left, and the right remained a powerful force to contend with after the Elections of I $936 .{ }^{2}$

Since it is an obvious impossibility to cover the whole range of rightist reactions to the Blum experiment within the limits imposed by a study of this type, attention will be focused on the attitudes of the middle and upper bourgeoisie-elements whose social conservatism and/or political authoritarianism placed them squarely among the most pronounced, if not always the most vocal opponents of the Front populaire. Such an emphasis is justifiable, not only because of the political, social, and economic importance of these classes, but also because any attempt to assess their role in the affair points to the need for further historical investigation. ${ }^{3}$

One must try to recapture the temper of the times in order to understand the controversies and passions aroused by the Front populaire. The trend of events from 1933 to 1936 was certainly of a nature to deepen the anxieties of the French middle classes. At home, the right's one big outburst, the Riots of February 6, 1934, had brought about no tangible results. The lingering depression and the chronic parliamentary instability thus led to continued, if somewhat helpless dissatisfaction with the regime. Abroad, the breakdown of collective security, the Ethiopian War, and especially the advent and consolidation of Nazi Germany bore witness to the hollowness of a victory won at a staggering cost. To these factors were now added the

${ }_{1}^{1}$ Louis Bodin \& Jean Touchard, Front populaire: 1936 [Collection Kiosque](Paris, 1961), p. 27.

2 Gordon Wright, France in Modern Times: 1760 to the Present (Chicago, 1960), p. 481 ; André Siegfried, De la IIIe à la IVe République (Paris, 1956), p. 59. Georges Dupeux emphasizes the fact that the Fédération républicaine, the most dynamic parliamentary faction of the right, made a net gain of 17 seats. See his Le Front populaire et les Elections de 1936 (Paris, 1959), p. 139 .

3 The middle bourgeoisie was composed of businessmen, professional men, owners of medium sized commercial and industrial enterprises, well-to-do gentlemen farmers, and upper level civil servants. In short, people who were a decided cut above the self-employed artisan, the owner of the corner boulangerie, the salaried employee, or low level fontionnaire. The author would equate the upper bourgeoisie with the world of big business. This included the owners and directors of large companies, the leaders of the banking and financial world, and other top level administrators and professional men. 
prospects of class warfare, the terrifying implications of the Spanish experience, the specter of bolshevism, and the increasing danger of another war.

Doubtless the realities of the situation did represent a threat to the security, vested interests, and aspirations of the French bourgeoisie. But these realities paled before the images conjured up by the rightist daily and weekly press. The solid citizen who bought Candide on Thursday, Gringoire on Friday, or Je suis partout on Saturday (or better yet, who bought all three as many did); ${ }^{1}$ who read dailies like Le Jour or l'Ecbo de Paris; and who, for good measure bought l'Action française at the church door on Sunday - this solid citizen lived in a never-never world of lurking shadows and sinister plots and conspiracies.

The publishers, directors, editors, and writers of the rightist press were aggressive, tireless, ruthless, coarse, unscrupulous, and totally irresponsible. They were more often than not, let it be said, able, clever, and entertaining journalists, who were virtuosos in the fine art of giving a semblance of credibility to the most outlandish and mendacious tales. ${ }^{2}$ The many renowned intellectuals among them lent an aura of respectability to the most sordid campaigns. Politics under the Third Republic had its seamy side, and the regime's enemies knew how to exploit the least opportunity to the full. Attracting as it did a widespread, gullible, and somewhat paranoid audience in influential circles, the rightist press did deep and lasting damage. ${ }^{3}$

The tenor of the electoral campaign was a portent of things to come. In a last ditch effort to avoid impending doom, the right whipped itself into a state of near hysteria long before the opening of the polls. ${ }^{4}$ Its candidates, press, and posters depicted a victory of the Front populaire in the most frightful terms. The most timid plank in the platform of the Rassemblement populaire was denounced as a radical and daring innovation; and the bourgeois fears of a bolshevik dictatorship exploited to the hilt.s "The Front populaire means war", was

1 This was the case for the author's French relatives and their circle of friends. With a circulation of 640,000 in November, 1936, Gringoire was the most important of the three. ${ }^{2}$ For a typical example of this approach to political writing, see Alain Laubreaux, La Terreur rose (Paris, I 939). Laubreaux was a contributor to Je suis partout.

3 "The venom of Gringoire and the Action frangaise had eaten deep into the French soul..." Alexander Werth, France: r940-1955 (New York, 1956), p. 22.

4 In fact, this reaction of the right anteceded the actual electoral campaign by some months. See the answers to Candide's inquiry: "Que se passerait-il avec un Gouvernement de Front populaire?", November 20, 1935. Gringoire interpreted the reoccupation of the Rhineland as " $\mathrm{l}$ 'Oeurre diplomatique du Front populaire", March $13,1936$.

5 Bodin \& Touchard, Front populaire, p. 28. 
another favorite theme. ${ }^{1}$ The Action française aptly summed it all up by advising its readers to vote against: "War and Revolution". ${ }^{2}$ In all fairness, it should be mentioned that the left was no less squeamish in exploiting the bogey of "fascism". ${ }^{3}$ There was little honest political debate in France during the Spring of 1936.

The fun did not really begin, however, until the second round of elections resulted in the Front populaire's victory by a wide margin. André Tardieu elegantly greeted the new majority as "révolutionnaires en peau de lapin, bétail d'abattoir".4 When the Communist deputies took their seats in the Chamber, Henri de Kérillis commented that the Palais Bourbon had been invaded by "seventy-two representatives from the Kremlin". ${ }^{5}$ Worse yet, as Xavier Vallat solemnly reminded the Chamber: "For the first time in her long history, France, that old Gallo-Roman country was about to be governed by a Jew."6 And not just any Jew at that, for Léon Blum was an old bête noire of the antiSemites of the extreme right. To them, his advent to the premiership marked the triumph of the métèques, the final surrender of the pays réel to the pays légal.7 The vulgarity and virulence of the attacks against the "artful Talmudist", the "circumcized hermaphrodite", the "public enemy No. I", who should be shot in the back, still come as a shock even to the latter-day observer whose hide has been thickened by the horrors of subsequent times. ${ }^{8}$

To many more French conservatives, whose sense of decency prevented them from joining in the chorus of abuse, the new Premier was also persona non grata. Their anti-Semitism was real though less out-

1 "La politique du Front commun cst une politique d'émigrés: il s'agit de réinstaller de force à Berlin et à Rome les épaves du communisme et du socialisme. Le Front populaire veut la guerre contre l'Allemagne et contre l'Italie pour y ramener les débris de l'internationale dans les fourgons de l'Armée française." Je suis partout, April i I, 1936.

${ }_{2}$ April 26, 1936.

3 "...Le caractère fondamental de la campagne des adversaires du Front populaire... est l'exploitation de la peur du communisme; il correspond exactement à l'un des caractères fondamentaux de la campagne des partis du Front populaire, l'exploitation de la peur du fascisme." Dupeux, Front populaire, p. I 20.

4 Gringoire, May I 5, I936.

5 Français, voici la Guerre! (Montrouge, 1936 ), p. 54.

6 Journal Officiel de la République Française, Débats Parlementaires, Chambre des Députés, June 7,1936, p. 1397.

7 "Ce que les dernières têtes raisonnables n'arrivaient pas à penser de sangfroid, c'était: la France, chef Léon Blum. Il ne se passait guère de jour sans que j'en ressentisse une insupportable humiliation." Lucien Rebatet, Les Décombres (Paris, 1942), p. 39. There were rumors that Blum had been born in Bessarabia, with the name Karfunkelstein. On this point, see Eugen Weber, Action Française (Stanford, I962), p. 375.

${ }^{8}$ For a handy compendium of the right's diatribes against Blum and the Front populaire, see Bodin \& Touchard, Front populaire, pp. 32-35, 200-216. 
spoken. Further, they objected to the tortuous bent of his mind, and had little faith in his capacity for leadership and power of judgment. ${ }^{1}$ Nor did they approve of the company he kept. As François Goguel has remarked: "In 1936, the bourgeoisie at once feared Léon Blum's weakness in the face of the revolutionary schemes of the Communists, and the energy with which he might try to bend the realities of the French situation to the concepts of doctrinaire Marxism."2 The campaign of calumnies was all too successful in substituting the caricature for the real man in the bourgeois mind. ${ }^{3}$ No wonder, then, that in conservative circles, Blum's beating on the occasion of Jacques Bainville's funeral should seem much less symbolic of the low level to which French politics had sunk, than Charles Maurras' imprisonment for incitement to murder. This outlook was succinctly expressed by one André Barbot: "Between M. Charles Maurras, an eminent writer and sincere patriot, and Léon Blum, this Hebrew full of hatred ... our choice is made." 4

Whether an other man might have been able to launch the "Ministry of the Masses" with greater chances of success is an academic question. The fact remains that, from the very first, to his enemies from the right, Léon Blum became the incarnation of the Front populaire and of all its evils. His frequent reminders that his was a Popular Front, not a Socialist government; that his mandate was restricted to the program of the Rassemblement populaire; and that he intended to operate within the framework of existing institutions and the capitalist system, failed to gain him the confidence of the financial and business community.5 Unfortunately for Blum, developments on the French scene and abroad played right into the hands of his enemies.

Today, all serious students of the question view the wave of sitdown strikes of May-June, 1936 , as the spontaneous outburst of long pent-up grievances and frustrations. ${ }^{6}$ At the time, they appeared to French property owners as the work of Bolshevik conspirators; as the first

${ }^{1}$ François Goguel, La Politique des partis sous la IIle République (Paris , 1946), p. 514.

2 Ibid.

3 Ibid., pp. 525-526.

4 Quoted in Weber, Action Française, p. 364.

5 "Peut-on espérer qu'un gouvernement de Front populaire obtiendra la confiance du capital et le repatriement des capitaux évadés? C'est pourtant à la tâche sans espoir de "créer un climat de confiance' que s'attachent les dirigeants du Front populaire." Jacques Danos et Marcel Gibelin, Juin 36 (Paris, I952), p. 224. Italics mine. See also Blum's declaration before the Chamber, J.O., Débats, Chambre, June 7, 1936, p. I335.

6 See, for instance, Val R. Lorwin, The French Labor Movement (Cambridge, Mass., 1954), p. 73; Henry W. Ehrmann, French Labor: From Popular Front to Liberation (New York, 1947), p. 38 ; Joel Colton, Compulsory Labor Arbitration in France, 19361939 (New York, 195 I), pp. 13-14; and Wright, France in Modern Times, p. 485. 
act of a new French Revolution. ${ }^{1}$ These bourgeois fears become more understandable when one recalls that no less an authority on such matters than Trotsky also misread the signs in the same direction. ${ }^{2}$ In any event, the jubilance with which the workers greeted their victory, following the signing of the Accords Matignon, overshadowed whatever relief the bourgeoisie may have felt at the gradual return of peace on the industrial front. In professor Tannenbaum's words, many wealthy citizens then "sought to avenge their hurt pride and to safeguard their threatened interests by supporting some form of authoritarianism". ${ }^{3}$

The dissolution of the rightist Leagues, later in the month, was widely interpreted as part of a plot to leave patriotic Frenchmen defenseless before the attacks of Moscow's well-armed, well-organized henchmen. ${ }^{4}$ And could anyone doubt that the reform of the Bank of France and the devaluation of the franc were but the first steps in a systematic attack on vested interests? In the meantime, high prices, the threat of inflation, and the prospects of budgetary deficits bore ample testimony to the ineptitude of Blum-la-misere. ${ }^{5}$ Had a France obsessed by a mythical "fascist threat" turned to the left merely to be confronted by the very real menace of a Communist dictatorship? 6

These fears were accentuated by the worsening of the international situation. The impact of the Spanish Civil War on the French right cannot be exaggerated. For here was living proof, and on France's very doorstep at that, of the logical and inevitable outcome of Popular Front experiments. The excesses of the Loyalists lost none of their savagery in the retelling by rightist reporters and correspondents, who conveniently overlooked the atrocities committed by the Franco forces. The desecration of churches and graveyards, and the martyrdom of nuns and priests were especially horrifying to the bien-pensant

\footnotetext{
1 See the editorial of Le Temps, June 13 , 1936, reproduced in Bodin \& Touchard, Front populaire, p. I Io. As late as I947, Pierre-Etienne Flandin still believed that the strikes had been organized by Communist leaders. See his Politique française, I 919-1940 (Paris, 1947), p. 213.

2 Jean Rous tells us that, at the height of the epidemic of strikes, he received the following telegram from Trotsky, who had then found a temporary asylum in Norway: "La Révolution Française a commencé." "Notes d'un militant. Vingt-cinq ans d'essais et de combats", in: Esprit (May, I956), p. 796.

3 The Action Française (New York, 1962), p. 219.

4 See Taittinger's and Vallat's speeches during the debate on the dissolution of the Leagues, J.O., Débats, Chambre, June 30, 1936, pp. 1634-1661. It was a riotous session. At one point, Speaker Herriot complained: “Il n'est même plus possible d'entendre les interruptions, mais celle que l'on me rapporte est inadmissible."!

5 Choc, November I2, 1936.

${ }^{6}$ François Herbette, l'Expérience marxiste en France, pp. 13 1-132.
} 
bourgeois. ${ }^{1}$ Naturally enough, the right immediately viewed the events in Spain as a struggle between "anti-Communist and proCommunist forces". And, of course, "a victory of the Soviets in Spain would mean Communism in Paris". Furthermore, as Pierre Gaxotte lost no time in reminding his readers in Candide: "French intervention in the Spanish Civil War would be the beginning of the European conflagration wanted by Moscow."2 Blum-la-misère once again made way for Blum-la-guerre. ${ }^{3}$ Since the nonintervention policy eventually alienated the Communists without in any way rallying the right, the Spanish Civil War ranks high among the causes for the ultimate defeat of the Front populaire.

Given the temper of the times, the achievements of the first Blum Ministry in the field of social legislation are worthy of respect. The right's reaction to this phase of the Front populaire experiment is especially interesting because "la droite se disait saciale". The Leagues spared no effort to woo the workers, and they always pointed with pride to the very few proletarians in their ranks. 4 The right, and especially the extreme right, indeed made a great show of its concern for the social problem, and of its sympathies with the aspirations of the working class. This attitude was particularly prevalent among young neo-national-socialists like Robert Brasillach, who would later accuse the Vichy regime of having betrayed the Révolution nationale. 5 For the moment, however, the problem was to undermine the Blum Government without seeming to run head-on against the legitimate demands of the workers. The right adopted the point of view that, though they had genuine grievances, the French workers were being used as pawns in the overall schemes of the Kremlin. ${ }^{6}$ Nothing much could be done until they had been removed from this evil tyranny. Free the worker from the contagion of Marxist propaganda, and the class struggle would wither away.7

1 For excellent reproductions of contemporary photographs and political cartoons on this subject, see René Rémond, Les Catholiques, le Communisme et les Crises [Collection Kiosque] (Paris, 1960), pp. 174-2II.

2 The above quotations are taken from Charles $A$. Micaud, The French Right and Nazi Germany, I 933-1939 (Durham, N.C., I943), pp. I I 4-I I 7 .

3 This was an old and favorite epithet of the Action française. See Tannenbaum, Action Française, p. 217

4 This was especially true of the Action française. See Samuel M. Osgood, French Royalism under the Third and Fourth Republics (The Hague, 1960), p. 93.

5 "C'est parce que nous sommes depuis toujours des nationaux-socialistes français que le Premier Mai est notre fête." Robert Brasillach in Je suis partout, May 2, 194I. See also his Notre Avant-guerre (Paris, 1941), p. 184; and Jean-Pierre Maxence, Histoire de dix ans, 1927-1937 (Paris, 1939), pp. 346-358.

6 Je suis partout, June $6 \& 20,1936$.

7 At least, so the Croix-de-feu believed. See Goguel, Politique des partis, pp. 475-476. 
The great popularity of corporative theories among the various exponents of the French right leads one to suspect that their intent was less to fulfill than to channel and control the demands of the workers for a fair stake in society. A former member of the Volontaires Nationaux fondly recalls the day he bumped into a young worker at the door of a Croix-de-feu recruiting center. The latter politely doffed his cap, stepped aside and said: "Après toi, Monsieur."1 The conservative vision of the bien pensant worker, ready to join in the great crusade for God and Country, yet who knew his place, simply was not of this world - at least until the advent of the Vichy regime. ${ }^{2}$ This is not to say that the rightists were insincere in their concern for the plight of the proletariat, but that theirs was the concern of a benevolent paternalism. To run a soup kitchen was one thing; to step aside while Léon Blum ushered in a workers' paradise was quite another. ${ }^{3}$

And so, while the government's problems multiplied, the fury of the anti-Semites mounted and the attacks against the Front COCUlaire gained new intensity. 4 Blum himself, Jean Zay, the Minister of Education, and Pierre Cot, the Minister of Aviation, were among the favorite targets of the rightist press. Particularly vicious was the campaign against Roger Salengro, the Socialist Minister of the Interior, whom Gringoire and the Action française accused, without any real foundation, of having deserted to the enemy during World War I. Although Salengro was cleared of all charges by a special court of inquiry, the campaign continued unabated into the Fall. After a heated debate in the Chamber, Salengro was vindicated by a vote of 427 to 103 . He committed suicide at his home in Lille four days later. 5 Well might Speaker Herriot remark, in his eulogy of the late Minister of the Interior before the Chamber of Deputies, that France was in the midst of a serious moral crisis. ${ }^{6}$

\footnotetext{
${ }^{1}$ Personal Testimony, Paris, I96r.

2 The many Petainists interviewed by the author recall fondly that under the Vichy Regime one knew exactly where one stood.

3 See André Tardieu's indignant article, "Les Funérailles du régime", in: Gringoire, June 26,1936 .

4 "Le Front coculaire est cacophonique." Je suis partout, September 26, 1936. The following is characteristic of contemporary anti-Semitic attitudes: "Nous serons capables pour assurer la défense du sol sacré de la patrie française de vendre aux enchères nos croixd'honneur, nos médailles et nos béquilles. Il se trouvera bien quelque juif, n'est-ce-pas? pour nous en donner quelques pièces..." Marcel Bucard in Le Franciste, March r4, 1937. 5 For good accounts of this episode, see Weber, Action Française, pp. 388-390; Bodin \& Touchard, Front populaire, pp. 2 ro-22x; and Rémond, Les Catholiques, le Communisme et les Crises, pp. $165-173$.

6 J.O., Débats, Chambre, November 24, 1936, p. 3024. "A la suite d'une campagne de presse, le ministre de l'Intérieur Roger Salengro, sans raison apparente, se suicidait", was Brasillach's comment, Notre Avant-guerre, p. I 88.
} 
But what did it all add up to? Was this politics of hate instrumental in shaping the course of events? To the extent that they poisoned the atmosphere; that they took a heavy spiritual toll out of a highly sensitive Premier; ${ }^{1}$ and that they complicated the task of an overburdened Ministry, the campaigns of the rightist press did contribute to the ultimate failure of the Front populaire experiment. ${ }^{2}$ It would be an exaggeration, however, to ascribe to the activities of the extreme right the major role in this failure. The inherent weaknesses in the Front populaire coalition, Léon Blum's shortcomings as a political leader and statesman, ${ }^{3}$ and especially the pressure of the international situation were more important factors. 4 In fact, it is not too farfetched to conclude that the worst enemies of the Front populaire did more to bring it into being than they did to bring it down. For it is hard to imagine the formation of the Front populaire in the first place, without February 6, 1934, without the "Fascist threat".5 And, after all, it was the refusal of the Radical-Socialists in the Senate to grant Blum's request for emergency financial powers that sounded the death knell of the great experiment.

Although they did not join the organizations of the extremists or participate in their campaigns, the overwhelming majority of the middle and upper bourgeoisie were hostile to the Front populaire. In retrospect, the Croix-de-feu movement, renamed the Parti Social Français after the dissolution of the Leagues, would seem to have been the prototype of the middle bourgeoisie's reaction to the challenges of the I930's. It was certainly the largest and the most "middle-class" of the Leagues. ${ }^{6}$ Deceived by appearances, the writers of all too many textbooks used by American students have pinned the fascist label on the Croix-de-feu. To be sure, they wore berets, and they were extremely fond of military

1 "Sa frémissante sensibilité lui fait ressentir comme blessures cruelles les moindres piqûres d'épingles." Jacques Chastenet, Déclin de la Troisième, I 93 I-I 938 (Histoire de la Troisième République, VI) (Paris, 1962), p. I I.

${ }^{2}$ For an assessment of the influence of both the leftist and the rightist press under the Front populaire, see Bodin \& Touchard, Front populaire, pp. 230-23I.

3 Collette Audry, Léon Blum ou la politique du juste (Paris, 1955), and Fernand Gouttenoire de Toury, Le Front populaire ruiné par ses chefs (Paris, 1939), serve as reminders that all criticisms of Blum's leadership did not come from the right.

4 "The Popular Front neither failed nor was it overthrown. It was smothered by the looming clouds of international crisis." David Thomson, Democracy in France (New York \& London, 1946), pp. I99-200.

5 At that, the Front populaire did not come into being until after long and tortuous negotiations. See Wright, France in Modern Times, pp. 477-480.

6 This evaluation of the Croix-de-feu is a working hypothesis based on the author's research on the subject to date. A comprehensive study of the movement has yet to be written. Here indeed is a virgin and fertile field for further inquiry. 
formations, secret orders, sudden mobilizations, marches and countermarches. But that is just about as far as it went. Colonel de La Rocque, their colorless and intellectually dull leader, never gave them the signal to march. In fact, the movement's real spurt did not start until it had been transformed into little more than just another political party. ${ }^{1}$ The diffident longings for a clean and "strong" government and for a more dynamic foreign policy, and the well-meaning but diffuse desire to do something to mitigate the sufferings of the poor and the unemployed, which permeate the Croix-de-feu's pronouncements and characterize their activities, typically reflect the fears, hesitations, and soul searching of the French middle class. ${ }^{2}$ Theirs was the reaction of solid, decent, and God-fearing citizens whose world had somehow gone wrong, but whose innate conservatism and respect for legality prevented them from engaging in mad adventures. Nothing so much confirms the impression of the Croix-de-feu as a moderate, middle-class movement than the attacks of the activists of the extreme right, who accused "Casimir de La Locque et les Froidesqueues" [sic!] of having harnessed what might have developed into a genuine revolutionary movement, capable of sweeping away not only the Léon Blums, but the hated parliamentary institutions as well. ${ }^{3}$ Instead, the Parti Social Français worked to capture parliament - through legal means. Many former members are convinced to this day that, but for the outbreak of World War II, the elections of r 940 would have swept La Rocque into power. ${ }^{4}$

We still know far too little about the politics of the upper bourgeoisie to reach a definite verdict about their role in the affair. ${ }^{5}$ It seems quite clear that the classes dirigeantes, as the French call them, viewed the

\footnotetext{
1 Rémond, Droite en France, p. 2 I4. Because of the lack of reliable statistical data it is difficult to determine the total membership of the Croix-de-feu (P.S.F.). On the basis of interviews with former members, and by weighing their claims against the figures of other observers, the author would estimate that, at its peak, the movement had well over one million members, and a much larger number of sympathizers among the middle bourgeoisie. This is no more than an educated guess.

2 For a brief but good summary of Croix-de-feu "doctrines", or lack of them, see Goguel, Politique des partis, pp. $475-476$.

3 Rebatet, Les Décombres, p. 39.

4 Personal Testimonies, Paris, $196 \mathrm{I}$.

5 This is another fruitful field for further study. Henry W. Ehrmann's, Organized Business in France (Princeton, 1957), represents a long step in the right direction. Unfortunately, from the standpoint of our knowledge of the role of big business in the 1930's, the bulk of this excellent work deals with the post-World War II period. The fourth volume of Emmanuel Beau de Loménie's thought provoking and controversial, Les Responsabilités des Dynasties bourgeoises (Paris, I963), ends in January, 1933, with the advent of the Nazi regime.
} 
formation of the Front populaire with considerable misgivings, and that they considered Blum's social and economic program to be calamitous. ${ }^{1}$ Moreover, many members of the patronat were angered by the extent of their defeat and later sought to minimize the effects of the Accords Matignon. ${ }^{2}$ One and all were especially eager to stem the Communist menace.

The practical expression of these fears and frustrations, however, is extremely difficult to unravel. The leaders of the business community always preferred to remain politically anonymous, and they were thus careful to cover up their tracks. We find some of their associates and representatives moving in extreme right circles. On the whole, however, their interest in and support of the Leagues seems to have been lukewarm and sporadic. ${ }^{3}$ Not that the upper echelons of the business community had any great fondness for democracy or attachment to parliamentary institutions. ${ }^{4}$ But they never felt their interests threatened to the extent which led their Italian and German counterparts to despair. The lack of support from High Capital can be mentioned as one of the important reasons for the failure of fascism to gather any real momentum in France. ${ }^{5}$ Why sponsor a La Rocque, why plunge into the political unknown, so long as a tried and true regime could provide a seemingly endless supply of Premiers, who were ready, willing, and had so far been able to protect the vested interests of the propertied classes? Why not wait and see whether another Poincaré stood in the wings ready to make his entrée en scène?

Of course, there were other ways of showing one's displeasure with the Blum Government. It was, for instance, in the bankers' and the investors' power to put the financial squeeze on the Treasury. The flight of gold and the reduced rate of capital investment during the early months of the Front populaire are sometimes presented as evidence of a deliberate plan to cripple and discredit the great experiment. Gold did leave France at an alarming rate after June, 1936- as it had throughout 1935 ; and the refusal to bring capital out of hiding amounted to a vote of no confidence in the policies of the government. Whether or not this was all part of a well synchronized plot to bring

${ }^{1}$ Goguel, Politique des partis, p. 358.

2 Jean Lhomme, "Quelques crises de la Société française: Juin 36", in: André Siegfried et al., Aspects de la Société française (Paris, 1954), pp. 85-87.

${ }^{3}$ For an interesting treatment of the fluctuating interest of the upper bourgeoisie in the Croix-de-feu, see H. Maisy, Groupes anti-parlementaires de droite (1933-1939) (Thèse, Institut d'Etudes Politiques, Paris, I952), pp. I 17 -1 19.

4 On these attitudes of business leaders, see Ehrmann, Organized Business in France, Chapter I: "From Matignon to the End of the Third Republic".

5 Danos \& Gibelin, Juin 36, pp. I9-20. 
down the Blum Ministry is problematic. ${ }^{1}$ Jacques Danos claims, with great authority, that the crisis of June, 1937, was carefully engineered by the City (Frenchmen are always ready to suspect the worst from the English), the great banks of Paris, Pierre Laval, and Blum's top financial advisors, who thereby betrayed their chief. In this light, Blum's request for emergency financial powers becomes the facesaving gesture of an already defeated man. ${ }^{2}$ Perhaps, but much more evidence is needed before such accusations and versions can be accepted as historical fact.

Léon Blum's announcement of a "pause" in the implementation of the Front populaire program, in February, 1937, failed to halt a decided swing of the pendulum back toward the right. The gains of the working class, the realization that the new wage scales were to apply to large and small enterprises alike, and a common fear of Communism served to reunite "the various categories of employers and all levels of the bourgeoisie". The lower bourgeois, who, in a moment of frustration and aberration, had voted Front populaire were now safely back in the fold. ${ }^{3}$ They had joined their more exalted brethren in the good fight against "Rooseveltism for Liliputians".4

The historian trying to pinpoint the ultimate cause for the failure of the Front populaire is confronted by an embarrassment of riches. There were, both at home and abroad, so many factors working against any chance of success, that one wonders whether the "Blum experiment" was not doomed from the start. Blum himself was later to recall that the whole of his first tenure had unfolded under the shadow of the Rhineland Crisis. ${ }^{5}$ In this context, the opposition of the right was at most a marginal factor. Yet, the fact that this opposition came to reflect the attitude of the whole French middle class certainly goes a long way to explain the ease and the speed with which the Front populaire was committed to the limbo of political experiments. One can only agree with the conclusion of Georges Dupeux, a leading French student of the question: "Although Léon Blum might easily have retained power, he gave up without much of

I Sec Wright, France in Modern Times, p. 487.

2 "Le Front populaire: Comment on mène la gauche à la défaite", in: Les Temps modernes, $\mathrm{X}$ (I I 2-I I 3, I955), pp. I 819-1 820 .

3 See Jean Lhomme's brilliant synthesis, “Quelques crises", pp. 86-87.

4 This bon mot is attributed to Joseph Caillaux. See D. W. Brogan, France under the Republic(New York \& London, 1940), p. 7 10.

5 "J'ai pu constater pendant toute la durée de mon Gouvernement la gravité et l'étendue vraiment infinie des dégâts, des ravages, que l'événement du 7 mars avait causés dans l'Europe entière." Evénements survenus en France, I, p. I 26. 
a fight because he was confronted by a bourgeoisie which had failed to accept, or even to understand, what he had to offer: the peaceful transformation of the socio-economic structure of the France of 1937."1

Coming at a time when the need for national unity was never greater, the schism engendered by the Front populaire had lasting and tragic consequences. It is not clear how many Frenchmen then began to look upon foreign intervention as a means of salvation from the threats of their political enemies at home. Did many Frenchmen really come to prefer "Hitler to the Front populaire?"2 At any rate, events were soon to show that many of them preferred Philippe Pétain to Léon Blum. One thing is certain, on the eve of World War II, at a crucial hour in the nation's destiny, all too many Frenchmen had succombed to the feeling that: "the only way to love France today, is to hate what she has become." 3

1 "L'Echec du premier Gouvernement Blum", in: Revue d'Histoire moderne et contemporaine, X (January-March, 1963 ), p. 44.

2 "Plutôt Hitler que le Front populaire, disent les hommes du grand capitalisme français." Victor Leduc, "Le Front populaire, Une étape", in: Les 'Temps modernes, X (I I 2-I I 3, 1955), pp. 1833-1834. Cf. Werth, France: I 940-1955, p. 23: "It was during the Popular Front days that the slogan 'Plutot Hitler que le Front Populaire' was launched - no one quite knows by whom. But it caught on."

3 Combat, April, 1937. Quoted in Raoul Girardet, "Note sur l'esprit d'un fascisme français”, in: Revue française de Science Politique, V (July-September, I955), p. 542. 